\title{
Letter to the Editor of Annals of Surgical Oncology Concerning "The Landmark Series: Multimodality Therapy for Stage 3A Non-small Cell Lung Cancer"
}

\author{
Naveen Kumar, MS, MCh, Sandeep Bhoriwal, MS, MCh, and Sunil Kumar, MS, FACS \\ Department of Surgical Oncology, All India Institute of Medical Sciences, New Delhi, India
}

\section{TO THE EDITOR}

We read the article titled "The Landmark Series: Multimodality Therapy for Stage 3A Non-small Cell Lung Cancer" by Eby et al. ${ }^{1}$ We thank and compliment the authors for a very nice review of two of the landmark trials for the management of stage $3 \mathrm{~A}$ lung cancer.

However, we would like to draw your kind attention toward some of the errors in this article:

1. The CONSORT diagrams of both trials are the same. The CONSORT diagram which was mentioned for Southwest Oncology Group (SWOG) 8805 trial is actually for Intergroup trial (INT) $0139 .^{2}$

2. In the results part of the INT 0139 trial review, the 5 -year survival is wrongly mentioned for different subgroups. The survival which is mentioned here is the median survival. In the original trial description, the respective median and 5-year survivals were 34.4 months and $41.0 \%$ for $\mathrm{T}$ (any)N0, 26.4 months and $23.8 \%$ for $\mathrm{T}$ (any)N1-3 or unknown, and 7.9 months and $8.3 \%$ for no surgical resection. ${ }^{3}$

\section{REFERENCES}

1. Eby ME, Seder CW. The Landmark Series: multimodality therapy for stage 3A non-small Cell lung cancer. Ann Surg Oncol. 2020;27(8):3030-3036. https://doi.org/10.1245/s10434-020-08553 $-\mathrm{z}$.

2. Albain KS, Rusch VW, Crowley JJ, et al. Concurrent cisplatin/ etoposide plus chest radiotherapy followed by surgery for stages IIIA (N2) and IIIB non-small-cell lung cancer: mature results of Southwest Oncology Group phase II study 8805. J Clin Oncol. 1995;13(8):1880-1892. https://doi.org/10.1200/jco.1995.13.8. 1880.

3. Albain KS, Swann RS, Rusch VW, et al. Radiotherapy plus chemotherapy with or without surgical resection for stage III nonsmall-cell lung cancer: a phase III randomised controlled trial. Lancet. 2009;374(9687):379-386. https://doi.org/10.1016/S01406736(09)60737-6.

Publisher's Note Springer Nature remains neutral with regard to jurisdictional claims in published maps and institutional affiliations.

(C) Society of Surgical Oncology 2020

First Received: 14 September 2020

Accepted: 17 September 2020;

Published Online: 22 October 2020

S. Kumar, MS, FACS

e-mail: dr_sunilk@hotmail.com 